\title{
Profil Kemampuan Berpikir Kritis Mahasiswa Program Studi Pendidikan IPA dalam Kasus Grafik Kinematika Satu Dimensi
}

\author{
Intan Ekananda Kirana ${ }^{1}$, Sentot Kusairi ${ }^{1}$ \\ ${ }^{1}$ Pendidikan Fisika-Universitas Negeri Malang
}

\begin{tabular}{l}
\hline \hline INFO ARTIKEL \\
\hline Riwayat Artikel: \\
Diterima: $25-02-2019$ \\
Disetujui: $16-03-2019$ \\
\hline
\end{tabular}

Kata kunci:

critical thinking skills; science students;

kinematics graph, kemampuan berpikir kritis; mahasiswa IPA; grafik kinematika

\begin{abstract}
ABSTRAK
Abstract: This study aims to examine students' critical thinking skills on a onedimensional kinematics graph. This quantitative descriptive model involved 51 final semester students and 32 early semester students. The test instrument was in the form of two description questions with 4 indicators of critical thinking skills, namely interpretation, analysis, evaluation, and inference. The results show that students have critical thinking skills in the low category, with the average score of the final semester students being slightly higher than the average grade of the early semester students. Students have difficulty determining the instantaneous speed of the graph of the time and displacement position of the time velocity graph.
\end{abstract}

\begin{abstract}
Abstrak: Penelitian ini bertujuan menguji kemampuan berpikir kritis mahasiswa pada grafik kinematika satu dimensi. Model deskriptif kuantitatif ini melibatkan 51 mahasiswa semester akhir dan 32 mahasiswa semester awal. Instrumen tes berupa dua soal uraian dengan empat indikator kemampuan berpikir kritis, yaitu interpretasi, analisis, evaluasi, dan inferensi. Hasil menunjukkan bahwa mahasiswa memiliki kemampuan berpikir kritis pada kategori rendah, dengan nilai rata-rata mahasiswa semester akhir sedikit lebih tinggi dari pada nilai rata-rata mahasiswa semester awal. Mahasiswa kesulitan menentukan kecepatan sesaat dari grafik posisi waktu dan perpindahan dari grafik kecepatan waktu.
\end{abstract}

\author{
Alamat Korespondensi: \\ Intan Ekananda Kirana \\ Pendidikan Fisika \\ Universitas Negeri Malang \\ Jalan Semarang 5 Malang \\ E-mail: enk.intan@gmail.com
}

Partnership for 21st Century Learning mengemukakan bahwa kemampuan berpikir kritis adalah salah satu elemen penting bagi peserta didik di Abad 21 (Chavez dan Napiere, 2014). Kemampuan berpikir kritis melibatkan komunikasi, berbicara, mendengarkan, membaca dan menulis serta lebih dari itu bisa dipraktikkan setiap hari dalam berbagai interaksi (MacKnight, 2000). Selain itu berpikir kritis juga bagian yang tidak terpisahkan dari aktivitas pemecahan masalah, kreativitas, penyelidikan dan juga pengambilan keputusan (MacKnight, 2000; Sumarna, 2017). Berpikir kritis bertujuan untuk penilaian regulasi diri, yang menghasilkan interpretasi, analisis, evaluasi, dan kesimpulan serta penjelasan tentang bukti, konseptual, metodologi, criteria atau pertimbangan kompleks yang mendasari penilaian itu (James dan Burton, 2017). Keterampilan berpikir kritis perlu dikembangkan dalam diri siswa karena melalui keterampilan berpikir kritis, siswa dapat lebih mudah memahami konsep, peka terhadap masalah yang terjadi sehingga dapat memahami dan menyelesaikan masalah dan mampu mengaplikasikan konsep dalam situasi yang berbeda (Scriven, 2008).

Berpikir kritis sebagai salah satu proses berpikir tingkat tinggi dapat digunakan dalam pembentukan sistem konseptual IPA peserta didik, sehingga merupakan salah satu proses berpikir konseptual tingkat tinggi (Liliasari, 2002). National Research Council (Education for Life and Work, 2012) mengemukakan bahwa kemampuan berpikir kritis sangat penting bagi mahasiswa, karena mahasiswa yang memiliki kemampuan berpikir kritis yang baik dapat menjadi konsumen sains yang kritis sehingga dapat menanggapai serta mengikuti berbagai perkembangan yang terjadi (Pradana, Parno, dan Handayanto, 2017). Beberapa hasil penelitian tentang kemampuan berpikir kritis di Indonesia menunjukkan kemampuan berpikir kritis mahasiswa masih rendah. Hasil penelitian yang dilakukan (Amrullah dan Suwarjo, 2018) menunjukkan bahwa rata-rata kemampuan berpikir kritis mahasiswa calon guru fisika hanya pada nilai 24,60 (sangat rendah). Penelitian lain yang dilakukan oleh (Pradana dkk., 2017) menunjukkan rata-rata kemampuan berpikir kritis mahasiswa fisika berada pada nilai, 24,29 (sangat rendah).

Kinematika merupakan salah satu cabang ilmu fisika yang sulit dipahami siswa. Kinematika menjadi konteks yang sulit bagi siswa meskipun mendapat pembelajaran di sekolah menengah (Planinic, Ivanjek, Susac, \& Milin-Sipus, 2013). Kesulitan yang banyak ditemui dalam pembelajaran kinematika adalah menginterpretasikan grafik. Representasi konsep grafis dan visual ke dalam verbal/ teks menjadi salah masalah yang muncul (Fry dan Hale, 2000; Shaffer, Squire, Halverson, dan Gee, 2005). 
Minimnya pengetahuan matematika bukan alasan utama kesulitan siswa dengan grafik, namun interpretasi makna fisika (Planinic, Milin-Sipus, Katic, Susac, dan Ivanjek, 2012). Siswa berhasil membuat grafik dengan garis-garis yang sesuai, namun tidak dapat menghubungkan makna grafik dengan konsep fisika yang mendasarinya (Nixon, Godfrey, Mayhew, \& Wiegert, 2016). Berdasarkan permasalahan di atas, perlu dilakukan pembuktian lebih lanjut dalam rangka menguji kemampuan berpikir kritis mahasiswa dalam bidang fisika. Tujuan penelitian ini adalah menguji kemampuan berpikir kritis mahasiswa pada grafik kinematika satu dimensi.

\section{METODE}

Model penelitian yang digunakan adalah deskriptif kuantitatif. Penelitian dilakukan dengan memberikan pertanyaan open ended materi kinematika satu dimensi. Sampel yang dijadikan sebagai subjek penelitian adalah 32 mahasiswa semester awal dan 51 mahasiswa semester akhir yang menempuh program studi S1 Pendidikan IPA. Instrumen tes terdiri dari dua soal uraian yang valid (soal no. $1<0,55>$; soal no. $2<0,53>$ ) dan reliabel $(0,747)$.

Proses pengambilan data dilaksanakan dengan membagikan soal kepada subjek dan dikerjakan selama 20 menit. Selanjutnya, hasil tes dianalisis dengan menggunakan rubrik penskoran yang dimodifikasi oleh Facione (1994) dan Ismaimuza (2013). Perincian penjabaran indikator dapat dilihat pada tabel 1.

Tabel 1. Penskoran Indikator Berpikir Kritis

\begin{tabular}{|c|c|c|}
\hline Indikator & Keterangan & Skor \\
\hline \multirow[t]{5}{*}{ Interpretasi } & Tidak menulis yang diketahui dan yang ditanyakan & 0 \\
\hline & Menulis yang diketahui dan yang ditanyakan dengan tidak tepat & 1 \\
\hline & Menulis yang diketahui saja dengan tepat atau yang ditanyakan saja dengan tepat & 2 \\
\hline & Menulis yang diketahui dari soal dengan tepat, tetapi kurang lengkap & 3 \\
\hline & Menulis yang diketahui dan ditanyakan dari soal dengan tepat dan lengkap & 4 \\
\hline \multirow[t]{5}{*}{ Analisis } & Tidak membuat model matematika dari soal yang diberikan. & 0 \\
\hline & Membuat model matematika dari soal yang diberikan tetapi tidak tepat. & 1 \\
\hline & Membuat model matematika dari soal yang diberikan dengan tepat tanpa memberikan penjelasan. & 2 \\
\hline & Membuat model matematika dari soal yang diberikan dengan tepat tetapi ada kesalahan dalam penjelasan. & 3 \\
\hline & $\begin{array}{l}\text { Membuat model matematika dari soal yang diberikan dengan tepat dan memberi penjelasan yang benar dan } \\
\text { lengkap }\end{array}$ & 4 \\
\hline \multirow[t]{5}{*}{ Evaluasi } & Tidak menggunakan strategi dalam menyelesaikan soal. & 0 \\
\hline & Menggunakan strategi yang tidak tepat dan tidak lengkap & 1 \\
\hline & $\begin{array}{l}\text { Menggunakan strategi yang tepat dalam menyelesaikan soal, tetapi tidak lengkap atau menggunakan strategi } \\
\text { yang tidak tepat, tetapi lengkap dalam menyelesaikan soal. }\end{array}$ & 2 \\
\hline & Menggunakan strategi yang tepat dalam menyelesaikan soal lengkap, tetapi melakukan kesalahan dalam & 3 \\
\hline & $\begin{array}{l}\text { perhitungan Menggunakan strategi yang tepat dalam menyelesaikan soal lengkap dan benar dalam } \\
\text { melakukan perhitungan }\end{array}$ & 4 \\
\hline \multirow[t]{5}{*}{ Inferensi } & Tidak membuat kesimpulan. & 0 \\
\hline & Membuat kesimpulan yang tidak tepat dan tidak sesuai dengan konteks soal & 1 \\
\hline & Membuat kesimpulan yang tidak tepat meskipun disesuaikan dengan konteks soal. & 2 \\
\hline & Membuat kesimpulan dengan tepat, sesuai dengan konteks tetapi tidak lengkap. & 3 \\
\hline & Membuat kesimpulan dengan tepat, sesuai dengan konteks soal dan lengkap. & 4 \\
\hline
\end{tabular}

Perolehan skor dikonversikan ke dalam skor persentase yang dihitung dengan Persamaan 1 sebagai berikut:

$$
\text { Nilai Persentase }=\frac{\text { Skor yang diperoleh }}{\text { Skor maksimum }} \times 100 \%
$$

Skor persentase diinterpretasikan ke dalam kategori kemampuan berpikir kritis yang tertera pada Tabel 2.

Tabel 2. Interpretasi Kategori Kemampuan Berpikir Kritis

\begin{tabular}{cl}
\hline Interpretasi & \multicolumn{1}{c}{ Kategori } \\
\hline $81,25<\mathrm{X}<100$ & Sangat Tinggi \\
$71,50<\mathrm{X}<81,25$ & Tinggi \\
$62,50<\mathrm{X}<71,50$ & Sedang \\
$43,75<\mathrm{X}<62,50$ & Rendah \\
$0<\mathrm{X}<43,75$ & Sangat Rendah \\
\hline
\end{tabular}

(Setyowati, 2011) 


\section{HASIL}

Penelitian ini menghasilkan nilai-nilai kemampuan berpikir kritis mahasiswa pada grafik kinematika satu dimensi. Nilainilai tersebut didapatkan dari hasil pre-test dan post-test. Hasil tes kemampuan berpikir kritis siswa ditampilkan pada Tabel 3.

Tabel 3. Statistik Deskriptif Kemampuan Berpikir Kritis Siswa

\begin{tabular}{lcc}
\hline Unsur Statistik & Mahasiswa Semester Awal & Mahasiswa Semester Akhir \\
\hline Jumlah & 32 & 51 \\
Mean & 31,12 & 47,06 \\
Standar Deviasi & 15,58 & 16,69 \\
Maksimum & 3,00 & 16,00 \\
Minimum & 72,00 & 91,00 \\
\hline
\end{tabular}

Tabel 3. menunjukkan bahwa nilai rata-rata mahasiswa semester awal sebesar $(31,12)$ lebih rendah dibandingkan nilai rata-rata mahasiswa semester akhir $(47,06)$. Berdasarkan Tabel II, nilai rata-rata mahasiswa semester awal memiliki kategori kemampuan berpikir krtitis sangat rendah, dan nilai rata-rata mahasiswa semester akhir memiliki kategori kemampuan berpikir kritis rendah. Hasil yang lebih spesifik mengenai ketercapaian indikator disajikan pasa gambar 1.

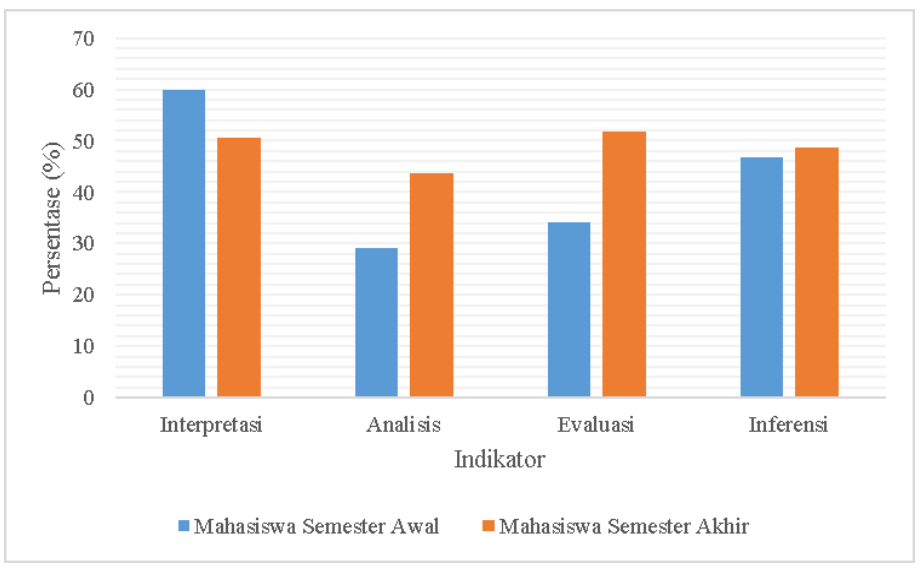

\section{Gambar 1. Grafik Ketercapaian Indikator Kemampuan Berpikir Kritis}

Indikator berpikir kritis analisis, evaluasi, dan inferensi menunjukkan bahwa mahasiswa semester akhir memiliki persentase lebih tinggi dari pada mahasiswa semester awal. Interpretasi mahasiswa semester awal lebih tinggi daripada mahasiswa semester akhir. Pembahasan yang lebih rinci disampaikan berdasarkan jawaban siswa pada tabel 4.

\section{Tabel 4. Jawaban Siswa Soal Nomor 1}

\begin{tabular}{|c|c|c|}
\hline 1 & \multicolumn{2}{|c|}{$\begin{array}{l}\text { Sebuah pasukan baris-berbaris bergerak di sebuah lapangan. Mula-mula pasukan } \\
\text { tersebut diam, kemudian bergerak ke arah utara dalam selang waktu tertentu. Gerak } \\
\text { pasukan baris-berbaris ditunjukkan dalam grafik di samping. }\end{array}$} \\
\hline Pertanyaan & Mahasiswa Semester Awal & Mahasiswa Semester Akhir \\
\hline $\begin{array}{l}\text { a) Deskripsikan secara lengkap } \\
\text { gerak pasukan baris-berbaris } \\
\text { berdasarkan grafik tersebut. }\end{array}$ & $\begin{array}{l}\text { Mendeskripsikan secara lengkap namun } \\
\text { beberapa arah gerak tidak tepat. }\end{array}$ & $\begin{array}{l}\text { Mendeskripsikan secara lengkap dengan arah gerak } \\
\text { yang tepat. }\end{array}$ \\
\hline $\begin{array}{l}\text { b) Pasukan baris-berbaris memiliki } \\
\text { kecepatan sebesar } 2,5 \mathrm{~m} / \mathrm{s} \text { ke arah } \\
\text { selatan pada saat } \mathrm{t}=60 \mathrm{~s} \text {. } \\
\text { Menurutmu, benarkah pernyataan } \\
\text { tersebut? Tunjukkan } \\
\text { perhitunganmu. }\end{array}$ & $\begin{array}{l}\text { Menuliskan besaran-besaran yang diketahui. } \\
\text { Menjawab "salah" namun memberikan } \\
\text { perhitungan dengan persamaan matematis } \\
\text { yang salah, sehingga menghasilkan nilai } \\
\text { kecepatan yang tidak diinginkan. } \\
\text { Memberikan kesimpulan pada akhir } \\
\text { jawaban. }\end{array}$ & $\begin{array}{l}\text { Tidak menuliskan besaran-besaran yang diketahui. } \\
\text { Menjawab "salah" disertai perhitungan yang } \\
\text { mendekati benar. Menentukan nilai gradien grafik } \\
\text { pada saat } \mathrm{t}=60 \mathrm{~s} \text {, namun koordinat yang digunakan } \\
\text { tidak sesuai sehingga menghasilkan nilai yang } \\
\text { kurang tepat. Memberikan kesimpulan pada akhir } \\
\text { jawaban. }\end{array}$ \\
\hline
\end{tabular}


Mahasiswa semester akhir dapat mendeskripsikan gerak benda berdasarkan grafik secara lengkap disertai arah gerak yang tepat, sedangkan mahasiswa semester awal mendapatkan kesulitan menyebutkan arah gerak berdasarkan grafik yang diberikan. Berdasarkan tabel 4, mahasiswa semester awal terbiasa menuliskan besaran-besaran dan nilai yang muncul pada soal, kemudian memasukkannya pada persamaan matematis yang mereka ingat dari pembelajaran di sekolah menengah. Berbeda dengan mahasiswa semester awal, mahasiswa semester akhir menggunakan persamaan matematis yang sesuai dengan konsep kinematika yang diinginkan oleh soal sehingga menghasilkan nilai yang benar (mendekati benar dalam soal 1b).

Tabel 5. Jawaban Siswa Soal Nomor 2

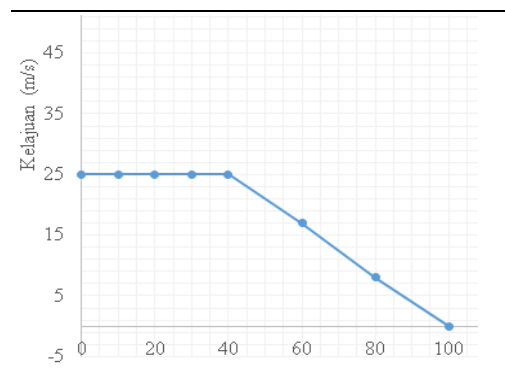

Gambar di samping menununjukkan grafik hubungan kelajuan-waktu dari gerak sebuah kereta. Setelah $100 \mathrm{~s}$ kereta berhenti di stasiun.

Pertanyaan

a) Hitung perpindahan yang dialami kereta pada interval waktu $40 \mathrm{~s}$ hingga $100 \mathrm{~s}$.

b) Setelah detik ke $100 \mathrm{~s}$, kereta berhenti dalam $80 \mathrm{~s}$. Kemudian kereta dipercepat menjadi $30 \mathrm{~m} / \mathrm{s}$ dengan percepatan 0,6 $\mathrm{m} / \mathrm{s}^{2}$. Kemudian bergerak dengan kecepatan konstan. Lengkapi grafik untuk interval waktu $100 \mathrm{~s}$ hingga $280 \mathrm{~s}$. Tunjukkan perhitunganmu.

\section{Mahasiswa Semester Awal}

Menuliskan besaran-besaran yang diketahui. Memberikan perhitungan dengan persamaan matematis yang benar $(s=\Delta v$. $\Delta t$; atau $s=$ $\left.v_{0} t-\frac{1}{2} a t^{2}\right)$, namun salah memasukkan nilai kecepatan sehingga menghasilkan nilai kecepatan yang tidak diinginkan. Memberikan kesimpulan pada akhir jawaban.

Tidak menuliskan besaran-besaran yang diketahui. Menggambar grafik dengan koordinat yang salah. Beberapa mahasiswa menemukan nilai yang tidak tepat berdasarkan perhitungannya, namun sebagian besar mahasiswa tidak memberikan perhitungan.

\section{Mahasiswa Semester Akhir}

Tidak menuliskan besaran-besaran yang diketahui. Memberikan perhitungan dengan persamaan matematis yang benar (luas area di bawah grafik), sehingga menghasilkan nilai kecepatan beragam. Benar menggunakan luas segitiga, salah menggunakan luas persegi panjang. Memberikan kesimpulan pada akhir jawaban.

Tidak menuliskan besaran-besaran yang diketahui. Menggambar grafik dengan koordinat yang beragam. Benar berdasarkan perhitungan yang benar, dan salah berdasarkan perhitungan yang tidak tepat. Memberikan kesimpulan di akhir jawaban.

Tabel 5 menunjukkan bahwa mahasiswa kesulitan menentukan perubahan posisi dari grafik hubungan kecepatan waktu. Mahasiswa semester awal cenderung menggunakan persamaan yang benar, namun tidak sesuai dengan konteks soal, sedangkan mahasiswa semester awal kesulitan menentukan luas daerah di bawah grafik (segitiga atau persegi panjang).

\section{PEMBAHASAN}

Berdasarkan hasil penelitian, diperoleh informasi bahwa kemampuan berpikir kritis mahasiswa semester awal berkategori sangat rendah, sedangkan kemampuan berpikir kritis mahasiswa semester akhir berkategori rendah. Mahasiswa tidak terbiasa dalam menganalisis permasalahan pada kasus yang buruk. Padahal, menganalisis kasus yang buruk akan mendongkrak sikap berpikir kritis dalam menyelesaikan permasalahan dengan tepat (Erceg \& Aviani, 2014). Kemampuan berpikir kritis membutuhkan strategi yang tepat dan perlu banyak latihan (Snyder \& Snyder, 2008).

Siswa kesulitan menentukan gradien dan daerah yang terdapat dalam grafik (Turner, Ellis, \& Beichner, 2014). Siswa kesulitan memahami konsep turunan sebagai gradien dan konsep integral sebagai daerah di bawah grafik (Planinic dkk., 2013). Dalam menentukan kecepatan pada grafik posisi-waktu, mahasiswa memberikan penyelesaian pada gradien grafik yang membawa mereka pada strategi berbeda (menggunakan persamaan matematis) dan tidak menggunakan penalaran mereka (Planinic dkk., 2013). Sejalan dengan pernyataan (Nixon dkk., 2016) bahwa mahasiswa menyelesaikan soal grafik dengan persamaan matematis tanpa konsep fisika. Sejalan dengan (Docktor \& Mestre, 2014) bahwa pemecah masalah yang baik menggunakan deskripsi untuk mengkonstruk persamaan matematis, sedangkan pemecah masalah yang tidak baik, tidak menggunakan representasi dalam menyelesaikan masalah.

Kesalahan yang banyak ditemukan yaitu menentukan perpindahan dari grafik kecepatan waktu. Penemuan ini sesuai dengan penelitian yang dilakukan oleh (Nguyen dan Rebello, 2011; Dominguez, Barniol, \& Zavala, 2017; Maries \& Singh, 2013; Nguyen \& Rebello, 2011; Planinic dkk., 2013) bahwa siswa mengalami kesulitan dalam menentukan luas daerah dibawah grafik. (Maries \& Singh, 2013) mengemukakan bahwa siswa mengalami kesalahan menentukan luas persegi panjang, bukan luas segitiga akibat peningkatan percepatan secara konstan. 
Pada saat proses pengambilan data, kelemahan yang ditemukan selama penelitian adalah kondisi lingkungan yang kurang baik. Oleh sebab waktu pengambilan data dilaksanakan di sore hari, konsentrasi mahasiswa tidak lagi optimal. Selain itu, kondisi kelas yang kurang kondusif juga memberikan pengaruh yang kurang baik dalam berpikir. Padahal, berpikir kritis mengharuskan kondisi yang optimal, baik dari internal ataupun eksternal. Untuk itu, dalam memberikan uji soal perlu dipertimbangkan waktu dan tempat yang sesuai. Selain itu, pada penelitian kali ini hanya diperoleh kategori kemampuan berpikir kritis mahasiswa. Untuk selanjutnya, bisa dikembangkan penelitian yang membahas mengenai permasalahan dalam berpikir kritis dan upaya untuk meningkatkan kemampuan berpikir kritis. Kemampuan berpikir kritis siswa masih rendah dikarenakan pengajaran tradisional tidak cukup untuk mengembangkan kemampuan berpikir kritis siswa (Erceg dan Aviani, 2014). Sebagai upaya untuk meningkatkan kemampuan berpikir kritis, pemberian strategi pembelajaran yang relevan sangat diperlukan. Salah satunya adalah dengan pembelajaran yang menekankan pada pemecahan masalah. Dengan banyak memecahkan masalah, kemampuan berpikir kritis akan meningkat. Pemberian latihan untuk memecahkan masalah akan meningkatkan kemampuan berpikir kritis (Tiruneh, Verburgh, \& Elen, 2014).

\section{SIMPULAN}

Mahasiswa semester akhir memiliki kemampuan berpikir kritis sedikit lebih tinggi daripada mahasiswa semester awal. Kemampuan berpikir kritis mahasiswa semester awal berkategori sangat rendah, sedangkan kemampuan berpikir kritis mahasiswa semester akhir berkategori rendah. Mahasiswa kesulitan menentukan kecepatan sesaat dari grafik posisi waktu dan perpindahan dari grafik kecepatan waktu.

Sebagai upaya untuk meningkatkan kemampuan berpikir kritis, pemberian strategi pembelajaran yang relevan sangat diperlukan. Salah satunya adalah dengan pembelajaran yang menekankan pada pemecahan masalah. Dengan banyak memecahkan masalah, kemampuan berpikir kritis akan meningkat. Pemberian latihan untuk memecahkan masalah akan meningkatkan kemampuan berpikir kritis.

\section{DAFTAR RUJUKAN}

Amrullah, K., \& Suwarjo, S. (2018). The Effectiveness of the Cooperative Problem-Based Learning in Improving the Elementary School Students' Critical Thinking Skills and Interpersonal Intelligence. Jurnal Prima Edukasia, 6(1), 6677. https://doi.org/10.21831/jpe.v6i1.11253

Chavez, J. C., \& Napiere, M. B. (2014). Learning Goal Orientation and Instructional Strategies: Predictors of Critical Thinking. Journal of Information Systems Technology dan Planning, 7(18), 117-127.

Docktor, J. L., \& Mestre, J. P. (2014). Synthesis of discipline-based education research in physics. Physical Review Special Topics - Physics Education Research, 10(2). https://doi.org/10.1103/PhysRevSTPER.10.020119

Education for Life and Work: Developing Transferable Knowledge and Skills in the 21 st Century. (2012). Washington, D.C. National Academies Press. https://doi.org/10.17226/13398

Erceg, N., \& Aviani, I. (2014). Students' Understanding of Velocity-Time Graphs and the Sources of Conceptual Difficulties.

Fry, A. F., \& Hale, S. (2000). Relationships among Processing Speed, Working Memory, and Fluid Intelligence in Children. Biological Psychology, 54(1), 1-34. https://doi.org/10.1016/S0301-0511(00)00051-X

James, N., \& Burton, K. (2017). Measuring the Critical Thinking Skills of Law Students Using a Whole-of-Curriculum Approach. Legal Education Review, 27(1).

MacKnight, C. B. (2000). Teaching Critical Thinking through Online Discussions. Educause Quarterly, 23(4), 38-41.

Maries, A., \& Singh, C. (2013). Exploring One Aspect of Pedagogical Content Knowledge of Teaching Assistants Using the Test of Understanding Graphs in Kinematics. Physical Review Special Topics - Physics Education Research, 9(2), 020120. https://doi.org/10.1103/PhysRevSTPER.9.020120

Nguyen, D. H., \& Rebello, N. S. (2011). Students' understanding and application of the area under the curve concept in physics problems. Physical Review Special Topics - Physics Education Research, 7(1). https://doi.org/10.1103/PhysRevSTPER.7.010112

Nixon, R. S., Godfrey, T. J., Mayhew, N. T., \& Wiegert, C. C. (2016). Undergraduate Student Construction and Interpretation of Graphs in Physics Lab Activities. Physical Review Physics Education Research, 12(1). https://doi.org/10.1103/PhysRevPhysEducRes.12.010104

Planinic, M., Ivanjek, L., Susac, A., \& Milin-Sipus, Z. (2013). Comparison of University Students' Understanding of Graphs in Different Contexts. Physical Review Special Topics - Physics Education Research, 9(2). https://doi.org/10.1103/PhysRevSTPER.9.020103[

Planinic, M., Milin-Sipus, Z., Katic, H., Susac, A., \& Ivanjek, L. (2012). Comparison of Student Understanding of Line Graph Slope in Physics and Mathematics. International Journal of Science and Mathematics Education, 10(6), $1393-1414$. https://doi.org/10.1007/s10763-012-9344-1

Pradana, S. D. S., Parno, P., \& Handayanto, S. K. (2017). Pengembangan Tes Kemampuan Berpikir Kritis pada Materi Optik Geometri untuk Mahasiswa Fisika. Jurnal Penelitian dan Evaluasi Pendidikan, 21(1), 51. https://doi.org/10.21831/pep.v21i1.13139 
Scriven M, Paul R. (2008). Defining Critical Thinking. The Critical Thinking Community: Foundation for Critical Thinking. Retrieved from http://www.criticalddnking.org/aboutCT/define_criticat_thinking.cfm. S

Shaffer, D. W., Squire, K. R., Halverson, R., \& Gee, J. P. (2005). Video Games and the Future of Learning. Phi Delta Kappan, 87(2), 105-111. https://doi.org/10.1177/003172170508700205

Snyder, L. G., \& Snyder, M. J. (2008). Teaching Critical Thinking and Problem Solving Skills. Delta Pi Epsilon Journal, 50(2), 90-99.

Sumarna, N. (2017). Peningkatan Kemampuan Pemahaman Matematis, Berpikir Kritis, Kreatif dan Penalaran Matematis pada Mahasiswa Calon Guru Sekolah Dasar melalui Pendekatan Pembelajaran Investigasi Matematik. Repository Indonesia University of Education. Retrieved from http://repository.upi.edu/id/eprint/28149

Tiruneh, D. T., Verburgh, A., \& Elen, J. (2014). Effectiveness of Critical Thinking Instruction in Higher Education: A Systematic Review of Intervention Studies. Higher Education Studies, 4(1). https://doi.org/10.5539/hes.v4n1p1

Turner, W. A., Ellis, G. W., \& Beichner, R. J. (2014). A Comparison of Student Misconceptions in Rotational and Rectilinear Motion. 2014 ASEE Annual Conference dan Exposition, 24.34.1-24.34.27. 